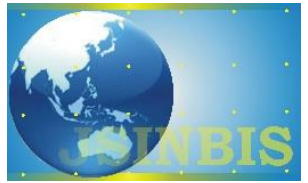

\title{
Penentuan Prioritas Pengambilan Pesanan Barang Oleh Angkutan Kota Dengan Metode Rule-Based System
}

\author{
Nur Aini Rakhmawati*, Aditya Septa Setya Budi, Faizal Johan Atletiko, Kartika Maulida \\ Hindrayani, Fajar Ramadhani, Sharfina Febbi Handayani
}

Jurusan Sistem Informasi Institut Teknologi Sepuluh Nopember Surabaya

Naskah Diterima : 12 Oktober 2018; Diterima Publikasi : 21 November 2018

DOI : 10.21456/vol8iss2pp195-202

\begin{abstract}
Angkotin is a system that provides an alternative for urban transport to not only be used for passenger transportation, but also as freight service. Therefore, it needs a decision support system for taking order to delivery to the destination according to each criterion from urban transportation. The method used to develop this decision support system is a rule-based system. The result of this research is a decision support system that can help public transportation to find orders that can be taken based on four factors, such as distance, direction, route code, and status of storage capacity. Based on these four factors, the system can provide an order recommendation under the appropriate conditions through the Angkotin application. Based on our experiment, our system performs on 7 seven cases as expected.
\end{abstract}

Keywords: Decision Support Systems; Dispatch Systems; Goods Shipment; Rule-Based System.

\begin{abstract}
Abstrak
Kecenderungan penurunan penggunaan layanan transportasi angkutan kota di Surabaya dapat diatasi dengan pembuatan sebuah sistem baru berbasis mobile bernama Angkotin. Sistem tersebut dapat memberikan alternatif angkutan kota agar tidak hanya dapat digunakan sebagai angkutan penumpang, tetapi juga jasa pengiriman barang. Oleh karena itu, diperlukan sebuah sistem pendukung keputusan untuk pengambilan pesanan yang sesuai dengan kriteria masing-masing dari angkutan kota hingga pengiriman ke tempat tujuan. Metode yang digunakan untuk mengembangkan sistem pendukung keputusan adalah sistem berbasis aturan (Rule-Based System). Hasil dari penelitian ini adalah sebuah sistem pendukung keputusan yang dapat membantu angkutan kota untuk menemukan pesanan yang dapat diambil berdasarkan empat faktor yang berpengaruh, yaitu jarak, arah perjalanan, kode trayek, dan status kapasitas penyimpanan angkutan kota. Dengan memperhatikan keempat faktor tersebut, sistem ini dapat menghasilkan rekomendasi pesanan pada kondisi yang sesuai melalui aplikasi Angkotin. Dari 7 test case yang dijalankan, semua kasus menghasilkan luaran yang sesuai dengan yang diharapkan.
\end{abstract}

Kata kunci: Sistem Pendukung Keputusan; Penentuan Pesanan; Pengiriman Barang; Rule-Based System.

\section{Pendahuluan}

Semakin meningkatnya jumlah masyarakat mengakibatkan kebutuhan akan tersedianya transportasi publik dan kepemilikan kendaraan semakin tinggi (Soehodho, 2017). Menurut Joewono et al. (2016), frekuensi tersedianya angkutan, kecepatan perjalanan, kinerja yang tepat waktu merupakan atribut kepuasan masyarakat. Dari beberapa atribut kepuasan masyarakat tersebut, kecepatan perjalanan merupakan indikator kinerja utama kepuasan masyarakat terhadap transportasi publik (Joewono et al., 2016).

Menurut Hariyono (2015), Kota Surabaya memiliki permasalahan pelik pada bidang transportasi yang menarik untuk dikaji, seperti sarana prasarana jalan yang kurang memadai, peningkatan jumlah kendaraan, hingga keberadaan angkutan masal atau *) Penulis korespondensi: nur.aini@ is.its.ac.id angkutan umum yang kurang diminati oleh masyarakat. Sementara itu, hadirnya transportasi berbasis online mengubah kendaraan pribadi menjadi angkutan umum yang memberikan kemudahan pelayanan distribusi barang dan jasa. Hal ini menimbulkan polemik persaingan antara angkutan dalam kota dan transportasi berbasis online. Karena kemudahan layanan yang diberikan transportasi online, masyarakat lebih memilih menggunakan jasa transportasi online di bandingkan menggunakan angkutan umum. (Prasetya dan Legowo, 2016). Kurangnya minat masyarakat untuk menggunakan angkutan masal atau angkutan umum disebabkan lamanya waktu menunggu penumpang, fasilitas yang tidak layak, serta seringnya terjadi tindak kejahatan seperti pencurian dan penipuan (Hariyono, 2015). Hal tersebut dianggap menurunkan produktifitas angkutan 
umum dan mengurangi pendapatan bagi penyedia jasa angkutan umum.

Berdasarkan permasalahan diatas, penelitian ini memberikan alternatif dalam mengoptimalkan penggunaan jasa angkutan umum penumpang menjadi angkutan umum yang juga berfokus pada jasa pengiriman barang. Tahir et al. (2005) berpendapat bahwa angkutan adalah sarana untuk memindahkan orang atau barang dari suatu tempat ke tempat lainnya. Tujuannya adalah untuk membantu orang atau kelompok orang dalam menjangkau tempat yang dikehendaki atau mengirim barang dari tempat asal ke tempat tujuan. Dalam penelitian ini produktivitas angkutan akan ditingkatkan dengan tidak hanya mengantarkan penumpang melainkan juga dapat mengirimkan barang, sehingga produktifitas angkutan kota dapat meningkat dengan mengurangi waktu pemberhentian guna menunggu penumpang.

Dalam mengirimkan barang tentu saja dibutuhkan prosedur yang digunakan untuk mengatur proses pengambilan pesanan dan pengiriman barang. Menurut Panjaitan et al. (2016), keputusan pelanggan untuk menggunakan jasa pengiriman barang terjadi apabila kualitas pelayanan pada perusahaan pengiriman barang tersebut sesuai dengan apa yang diharapkan pelanggan. Hal ini dilakukan untuk menghindari terjadinya tumpang tindih dalam pengambilan pesanan dan berbagai kesalahan yang mungkin terjadi dalam pengiriman barang.

Salah satu metode yang dapat digunakan dalam proses penentuan pengambilan pesanan dan pengiriman barang adalah rule-based system. Rulebased system dapat digunakan misalnya untuk menentukan lokomotif yang digunakan, rolling stock, tim perbaikan, tim manajemen, dll pada penelitian yang dilakukan oleh Wheatley (1984). Menurut Wheatley (1984), dengan menggunakan rule-based system dapat menggunakan pengetahuan mengenai hubungan yang logis dengan sistem yang digunakan, sehingga lebih efektif. Pada penelitian yang dilakukan oleh Mansyur et al. (2013), rule-based system digunakan untuk memilih kebijakan yang sesuai dalam manajemen permintaan travel. Sistem tersebut sukses diimplementasikan karena mudah untuk dipelihara, dimodifikasi, dan dikembangkan. Adapun Asadi et al. (2015) menggunakan rule-based untuk menemukan solusi rute, penjadwalan, dan penugasan di manajemen transportasi Hazmat.

Dari penelitian yang telah dilakukan menunjukkan bahwa rule-based system dapat digunakan untuk kasus transportasi seperti pada penelitian ini. Faktor yang akan dipertimbangkan dalam penyusunan aturan adalah jarak, arah perjalanan, kode trayek, dan status kapasitas penyimpanan angkutan kota.

Penelitian ini terbagi menjadi lima bagian, bagian pertama merupakan pendahuluan yang berisi latar belakang dan permasalahan yang akan dijawab. Bagian kedua merupakan kerangka teori yang berisi tinjauan literatur yang mendukung penelitian ini.
Bagian ketiga merupakan metodologi yang digunakan dalam menyelesaikan penelitian ini. Pada bagian keempat membahas hasil penelitian berupa aplikasi yang dihasilkan dengan metode rule-based system. Bagian kelima merupakan kesimpulan dari penelitian ini.

Dengan menggunakan metode rule-based system, penelitian ini bertujuan mengembangkan aplikasi berbasis mobile yang diusulkan dengan nama "Angkotin". Angkotin memungkinkan pengguna untuk melakukan pengiriman barang dengan melalui perantara aplikasi.

\section{Kerangka Teori}

\subsection{Sistem Pendukung Keputusan}

Sistem pendukung keputusan merupakan sistem informasi interaktif yang menyediakan informasi, pemodelan dan manipulasi data. Sistem ini digunakan untuk membantu pengambil keputusan dalam situasi yang tidak terstruktur dimana tidak seorangpun tahu secara pasti bagaimana keputusan seharusnya dibuat (Sudjatmiko, 2013). Sistem pendukung keputusan adalah sistem berbasis komputer yang dibangun lewat sebuah proses adaptif dari pembelajaran, pola-pola penggunaan dan evolusi sistem (Turban et al, 2011). Berdasarkan pengertian tersebut dapat disimpulkan bahwa sistem pendukung keputusan merupakan sistem yang mampu memberikan kemampuan pemecahan masalah yang bersifat semi terstruktur dan tidak terstruktur.

Menurut Turban et al. (2011), sebuah sistem pendukung keputusan terdiri dari empat buah komponen, yaitu : subsistem manajemen data, subsistem manajemen model, subsistem antarmuka, subsistem manajemen berbasis pengetahuan. Subsistem manajemen data terdiri dari basis data yang berisi data yang relevan untuk situasi yang terjadi dan dikelola dalam sebuah piranti lunak yang disebut database management system (DBMS). Subsistem manajemen model adalah sebuah paket piranti lunak yang meliputi model keuangan, statistik, ilmu manajemen, atau model kualitatif lainnya yang menyediakan kemampuan analitis bagi sistem dan manajemen piranti lunak yang layak. Subsistem antarmuka berfungsi sebagai penghubung pengguna dengan sistem. Pengguna dapat berkomunikasi dan memberi perintah pada sistem dengan menggunakan komponen-komponen yang disediakan pada antarmuka. Subsistem manajemen berbasis pengetahuan dapat berdiri sebagai komponen yang berdiri sendiri maupun komponen yang mendukung komponen lain. Subsistem ini berfungsi untuk menyediakan intelijen untuk kepentingan pengambil keputusan.

\subsection{Rule-Based System}

Sebuah sistem berbasis aturan terdiri dari aturan ifthen, sekelompok fakta, dan seorang penerjemah yang 
mengontrol penerapan aturan, berdasarkan fakta (Abraham, 2005). Aturan rule-base system dapat direpresentasikan dengan 'Jika $\mathrm{x}$ adalah A, maka $\mathrm{y}$ adalah $B$ ' dan bagian-jika dari aturan ' $\mathrm{x}$ adalah $\mathrm{A}$ ' disebut anteseden atau premis, sedangkan bagianbagian selanjutnya dari aturan 'y adalah B' disebut konsekuensi atau kesimpulan.

\section{IF condition}

AND condition 2

OR condition3 (antesenden)

THEN action1, action2, action3, ... (kesimpulan)

Terdapat dua pendekatan yang digunakan dalam penerapan rule-based system yaitu pendekatan forward chaining dan backward chaining. Dalam sistem forward-chaining, fakta diproses terlebih dahulu, selanjutnya menggunakan aturan yang tersedia untuk menarik kesimpulan baru. Dalam sistem backward chaining, hasil hipotesis diproses terlebih dahulu, dan terus mencari aturan yang memungkinkan untuk menyimpulkan hipotesis tersebut.

Asadi et al. (2015) membangun sebuah sistem pendukung keputusan berbasis aturan untuk menemukan solusi rute, penjadwalan dan penugasan pada manajemen transportasi Hazmat. Hal yang menjadi pertimbangan pada sistem tersebut adalah frekuensi dan tingkat keparahan kecelakaan. Manajemen Hazmat membutuhkan sebuah solusi yang dapat menurunkan resiko kecelakaan dan biaya transportasi dengan efisien. Pada sistem tersebut, performa yang dihasilkan lebih tinggi daripada apabila menggunakan model optimisasi.

\subsection{Angkotin}

Angkotin merupakan sebuah aplikasi pengiriman barang dengan menggunakan jasa angkutan kota di Kota Surabaya. Dengan aplikasi Angkotin pengguna dapat mengirimkan barang ke berbagai daerah di Kota Surabaya melalui pos-pos pengiriman. Aplikasi ini memungkinkan pengguna untuk melakukan pengiriman barang dengan melalui perantara aplikasi. Selanjutnya barang akan diambil oleh angkutan kota untuk dikirimkan ke pos terdekat dengan lokasi tujuan pengiriman.

Selain modul pengiriman barang, pada aplikasi Angkotin juga terdapat modul penentuan harga, modul penentuan angkutan kota, dan modul tracking pengiriman. Keakuratan dalam menentukan angkutan kota mana yang akan mengambil pesanan merupakan salah satu hal yang cukup krusial. Karena jika terjadi kesalahan dalam penentuan angkutan kota dapat mengakibatkan kesalahan pengiriman barang. Maka dari itu pada penelitian ini akan dikembangkan modul penentuan angkutan kota dalam pengambilan pesanan pada aplikasi Angkotin.

\section{Metode}

\subsection{Tahap Pengumpulan Data dan Analisis Kebutuhan}

Pada tahap ini hal pertama yang dilakukan adalah mempelajari dan menganalisa proses bisnis yang terdapat pada aplikasi Angkotin, terutama yang berkaitan dengan modul penentuan angkotan kota.

Setelah mengetahui proses bisnis yang telah ditentukan, maka tahapan selanjutnya adalah menganalisis kebutuhan apa saja yang diperlukan dalam pengembangan aplikasi untuk menentukan pengambilan dan pengiriman pesanan barang.

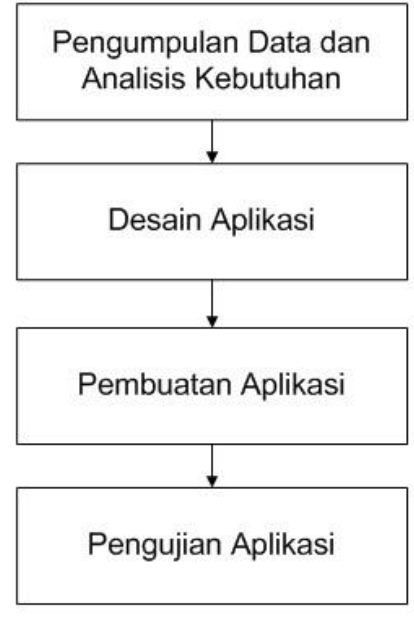

Gambar 1. Alur Penelitian

Kebutuhan dapat dibedakan berdasarkan pengguna dari aplikasi seperti pelanggan, pos, dan driver. Pelanggan berhak mengetahui status pesanan yang telah dikirimkan melalui Pos atau istilah umumnya melacak pesanan. Pesanan dapat dilacak dengan memasukkan nomor resi yang telah diterima kedalam sistem pemantauan pengiriman barang. Driver dapat mengubah status kapasitas dan status ketersedian yang digunakan sebagai masukan untuk sistem dalam menentukan ketersediaan driver dalam mengambil pesanan. Selain itu, driver akan menerima pesanan yang diteruskan dari hasil sistem pendukung keputusan. Driver juga dapat menerima atau menolak pesanan tersebut. Peran dari Pos pada sistem pendukung keputusan ini adalah sebagai inisiator untuk mengajukan sebuah pesanan yang diterima dari pelanggan dengan cara mengisikan beberapa informasi yang dibutuhkan oleh sistem. Setelah pesanan diterima maka Pos perlu mengetahui status pesanannya dan siapa yang akan mengambil pesanan tersebut. Selain itu Pos juga berperan dalam memverifikasi pengambilan pesanan oleh Driver angkot.

Berdasarkan pengamatan terhadap proses bisnis Angkotin, maka untuk menentukan angkutan kota mana yang dapat mengambil pesanan ditentukan berdasarkan beberapa variabel, seperti : 
a. Kode trayek merupakan kode yang menentukan rute perjalanan sebuah angkutan kota. Dalam penentuan pengambilan pesanan, kode trayek angkutan kota disesuaikan dengan jalur pengiriman barang. Apabila kode trayek sesuai maka angkutan kota tersebut memenuhi satu aturan untuk dapat mengambil pesanan.

b. Jarak merupakan jarak antara angkutan kota dengan lokasi pemesan. Dalam penentuan angkutan kota, perlu didefinisikan jarak maksimal untuk menyaring angkutan kota mana yang dapat memenuhi aturan tersebut. Misal jarak maksimal antara angkutan kota dengan lokasi pemesan adalah sejauh 1 kilo meter.

c. Kapasitas angkutan kota merupakan kondisi yang menyatakan status kapasitas dari angkutan kota, dimana terdapat dua status yaitu penuh dan tidak penuh. Jika kondisi angkutan kota masih memiliki tempat kosong, maka kendaraan tersebut memenuhi satu aturan untuk dapat mengambil pesanan.

d. Arah perjalanan menggambarkan arah perjalanan angkutan kota dibandingkan dengan arah perjalanan dari pengiriman barang. Hal ini menjadi pertimbangan sistem untuk memberikan pesanan yang memiliki arah yang sama dengan arah perjalanan angkutan kota. Untuk mengetahui arah perjalanan angkutan kota, sistem perlu mengetahui minimal dua posisi terakhir dari angkutan kota. Kedua titik tersebut akan dihitung masing-masing jaraknya terhadap titik asal (lokasi penjemputan barang) dan titik tujuan (lokasi tujuan pengiriman barang). Perhitungan untuk menentukan arah dapat diilustrasikan seperti pada Gambar 2.

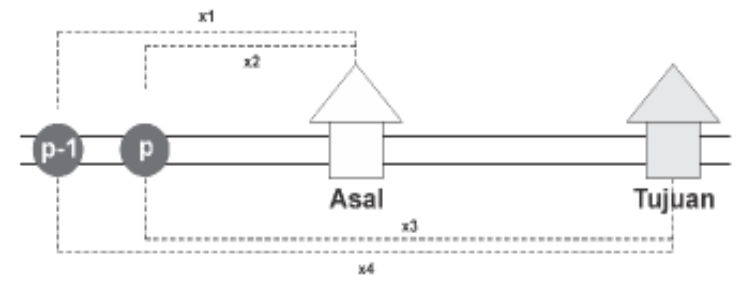

Gambar 2. Ilustrasi penghitungan untuk menentukan arah

Keterangan:

$\mathrm{P}=$ Posisi terakhir angkot

$\mathrm{P}-1$ = Posisi angkot sebelumnya

$\mathrm{X} 1$ = Jarak P-1 menuju titik Asal

$\mathrm{X} 2$ = Jarak P menuju titik Asal

$\mathrm{X} 3$ = Jarak P menuju titik Tujuan

X4 = Jarak P-1 menuju titik Tujuan

Setelah mengetahui jarak dari dua posisi terakhir terhadap titik asal dan titik tujuan, maka untuk mengetahui kecocokan arah perjalanan angkutan kota terhadap arah perjalanan pengiriman barang adalah dengan memenuhi syarat berikut :

$\mathrm{X} 1>\mathrm{X} 2$

$\mathrm{X} 4>\mathrm{X} 3$

$\mathrm{X} 2<\mathrm{X} 3$
Dengan memenuhi persyaratan tersebut maka dapat diketahui bahwa posisi angkutan kota sedang menuju titik asal dan titik tujuan.

Data trayek angkutan kota dan data geografis Kota Surabaya yang digunakan berdasarkan Google Maps. Kemudian data terkait perjalanan angkutan kota yang digunakan berdasarkan hasil keluaran kalkulasi dari Google Maps. Sementara itu, data pelanggan, pos, dan sopir angkutan kota yang digunakan merupakan dataset yang dikembangkan untuk penelitian ini.

\subsection{Tahap Desain Sistem}

Hasil analisis kebutuhan pada tahap sebelumnya akan digunakan untuk membuat gambaran desain dari fitur dan fungsionalitas aplikasi. Pada tahap ini akan dibuat beberapa desain secara bertahap antara lain desain basis data, desain model, desain antarmuka pengguna dan desain arsitektur sistem.

Pada tahap desain model, dilakukan perancangan alur dari model berdasarkan metode rule-based dengan menggunakan variabel yang telah ditentukan. Variabel dari tahapan kebutuhan ditambahkan pada aturan rule-based system. Model digunakan untuk mengklasifikasi angkutan kota yang akan menjadi kandidat untuk mengambil pesanan. Luaran (output) dari model ini berupa daftar pesanan yang dapat diambil driver sesuai dengan rute perjalanan pengiriman barang. Dalam pembuatan model terdapat empat variabel yang harus dipenuhi oleh sebuah angkutan kota agar dapat menjadi kandidat, yaitu arah perjalanan angkutan kota, kapasitas, kesesuaian kode trayek, dan jarak maksimal terhadap paengiriman barang.

Keempat variabel tersebut akan dijadikan sebuah aturan (rule) untuk membuat sebuah rule based systems. Dari penentuan variabel berdasarkan pengamatan proses bisnis yang telah dilakukan, dirumuskan empat aturan sebagai berikut :

1. If (kapasitas angkot $=0$ (tidak penuh)) Then...

2. If (kode trayek angkot $=$ kode trayek pengiriman) Then...

3. If (arah angkot $=$ arah pengiriman) Then...

4. If (jarak angkot $<500 \mathrm{~m}$ ) Then...

Keluaran (output) dari model ini adalah sebuah daftar pesanan yang dapat diambil oleh Driver. Skema rule-based system terlihat seperti Gambar 3 dibawah ini.

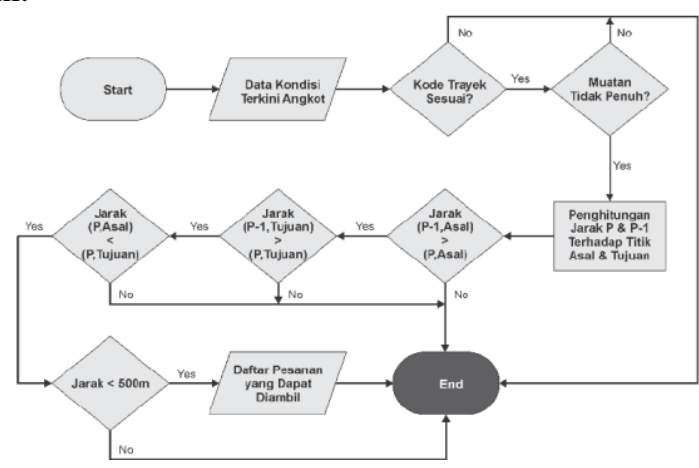

Gambar 3. Skema rule-based system 
Model yang dikembangkan pada pembuatan sistem pendukung keputusan ini berorientasi pada Driver, sehingga objek yang dicari adalah pesanan yang memenuhi kriteria untuk dapat diambil oleh Driver. Apabila sebuah pesanan memenuhi seluruh kriteria yang digambarkan pada model, yaitu mengenai kapasitas, kode trayek, arah, dan jarak maka pesanan tersebut dapat diambil oleh Driver.

Pada tahap desain arsitektur sistem, tahap ini menjelaskan mengenai arsitektur sistem yang akan dibuat beserta komponennya. Gambaran dari arsitektur sistem dapat dilihat pada Gambar 4.

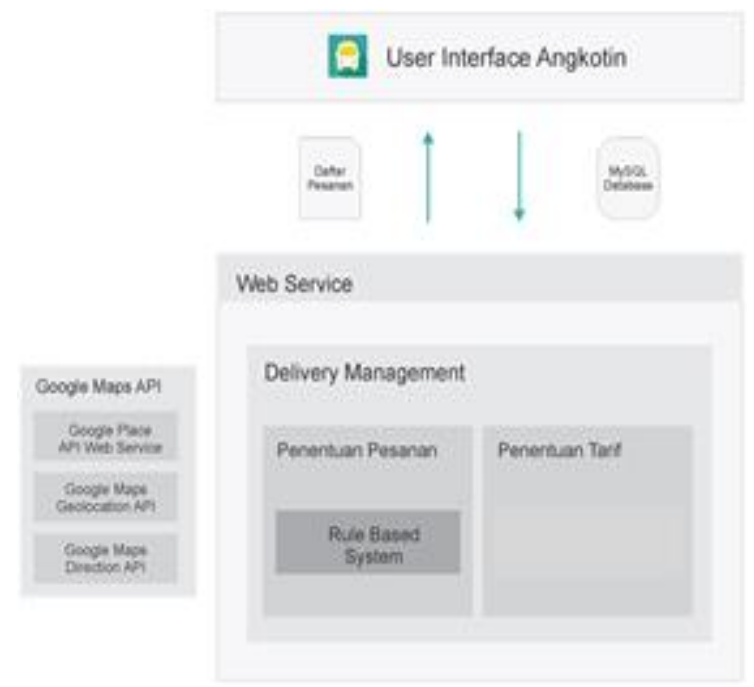

Gambar 4. Arsitektur Aplikasi Angkotin

Berdasarkan Gambar 4, terdapat dua proses utama dalam aplikasi Angkotin, yaitu penentuan pesanan dan penentuan tarif. Penentuan pesanan merupakan proses untuk menentukan daftar pesanan yang diambil oleh sebuah angkutan kota. Pada proses ini keempat faktor variabel yang mempengaruhi status sebuah pesanan digunakan sebagai sebuah aturan dalam pembuatan model rule-based system. Adapun penentuan tarif merupakan proses untuk menentukan tarif yang dikenakan pada suatu pengiriman barang. Beberapa faktor yang mempengaruhi tarif adalah berat, jumlah dan volume.

\subsection{Implementasi Sistem}

Setelah tahap desain selesai dilakukan kemudian masuk pada tahapan implementasi atau coding terhadap model yang telah dirancang dan mengintegrasikannya dengan aplikasi Angkotin yang sudah ada. Selain itu juga dilakukan pembuatan tampilan antar muka dari aplikasi sesuai dengan kebutuhan fungsionalitas.

Implementasi dilakukan dengan Intel ${ }^{\circledR}$ Core $^{\mathrm{TM}}$ i77200U CPU @ 2.50GHz, 8 GB RAM, Windows 10 Education, dan 64-bit Operating System, x64-based processor. Webserver yang digunakan adalah, bahasa pemrograman yang digunakan adalah PHP 7.1, Javascript, CSS, dan database yang digunakan adalah
MySQL (client). Sistem dapat diakses pada browser Google Chrome 56. Framework yang digunakan dalam implementasi adalah framework CodeIgniter, framework open source aplikasi berbasis web yang untuk bahasa pemrograman PHP. Selain itu, API Google Maps digunakan untuk mengembangkan aplikasi Angkotin, terutama untuk pengembangan modul - modul terkait pemilihan rute pengiriman dan modul penentuan angkutan kota. Bagian yang diambil dari API tersebut diantara lain location, direction, dan distance.

\subsection{Pengujian}

Pada tahap pengujian dilakukan pengujian aplikasi dalam rangka memastikan proses pengkodean yang telah dilakukan dapat berjalan dengan baik. Terdapat dua tujuan utama dilakukannya proses pengujian, yaitu untuk mengetahui apakah aplikasi berjalan sesuai dengan yang telah dirancang dan mencatat semua bug dan error yang ada serta menguji ketepatan dari rekomendasi hasil luaran dari model. Pengujian dilakukan setelah proses pengkodean selesai dilakukan.

Terdapat delapan fitur fungsional yang akan diuji. Tiga fitur yang digunakan driver yang akan diuji adalah pengambilan pesanan, pengiriman pesanan, dan lihat muatan. Fitur yang dapat diakses pelanggan yang akan diuji adalah pelacakan status pengiriman. Kemudian, terdapat empat fitur pos yang akan diuji yaitu menampilkan rute pengiriman, membuat pesanan, verifikasi pengambilan pesanan, dan verifikasi penerimaan pesanan.

Selain pengujian fungsional, pengujian rekomendasi dilakukan dengan memvalidasi hasil dari sistem pendukung keputusan melalui simulasi rekomendasi pada empat skenario yang berbeda. Pengujian rekomendasi dilakukan untuk mengetahui ketepatan rekomendasi yang dihasilkan dari sistem pendukung keputusan mengenai ketersediaan angkutan kota dalam mengambil pesanan.

\section{Hasil dan Pembahasan}

Pengujian untuk memastikan aplikasi dapat berjalan dengan baik dilakukan dengan pengujian fungsional dan pengujian rekomendasi. Pengujian fungsional pada aplikasi dilakukan dengan menggunakan metode blackbox testing. Pengujian tersebut dilakukan untuk mengetahui apakah fitur yang dibuat pada aplikasi dapat berjalan dengan baik. Fitur yang akan dicoba hanya pada fitur utama aplikasi, yaitu terdapat delapan fitur.

Pada fitur F01-Menampilkan rute pengiriman, data yang dimasukkan adalah data titik asal dan titik tujuan. Ekspektasi hasilnya adalah aplikasi dapat menampilkan rute pengiriman dan kode trayek angkot. Hasil aktual dari pengujian fitur ini sesuai dengan ekspektasi hasil, namun terdapat beberapa kasus kode trayek tidak muncul. 
Pada fitur F02-Membuat pesanan, data yang dimasukkan adalah Titik Asal, Titik Tujuan, Nama Pengirim, Nama Penerima, dan Deskripsi Barang. Ekspektasi hasilnya adalah Sistem dapat menyimpan data pesanan. Hasil aktual dari pengujian fitur ini sesuai dengan ekspektasi hasil, yaitu tidak ditemukan adanya kesalahan.

Pada fitur F03-Verifikasi pengambilan pesanan, data yang dimasukkan adalah Data Pesanan dan ID Driver. Ekspektasi hasil dari fitur ini adalah pos dapat memverifikasi pesanan dan barang yang telah diverifikasi masuk kedalam muatan Driver. Hasil aktual dari pengujian fitur ini sesuai dengan ekspektasi hasil, yaitu tidak ditemukan adanya kesalahan.

Pada Fitur F04-Verifikasi Penerimaan Pesanan, data yang dimasukkan adalah Data Pesanan dan ID Driver. Ekspektasi hasil dari fitur ini adalah pos dapat memverifikasi barang dari Driver dan barang yang telah diverifikasi dihapus dari muatan Driver. Hasil aktual dari pengujian fitur ini sesuai dengan ekspektasi hasil, yaitu tidak ditemukan adanya kesalahan.

Pada Fitur F05-Lacak Status Pesanan, data yang dimasukkan adalah Nomor resi pengiriman barang. Ekspektasi hasil dari fitur ini adalah menampilkan riwayat dan status pengiriman barang. Hasil aktual dari pengujian fitur ini sesuai dengan ekspektasi hasil, yaitu tidak ditemukan adanya kesalahan.

Pada Fitur F06-Ambil Pesanan, data yang dimasukkan adalah Data lokasi Driver, Data lokasi pesanan. Ekspektasi hasil dari fitur ini adalah Memunculkan lokasi pesanan yang dapat diambil Driver, Melihat detail dari pesanan, Mengambil pesanan, Menolak pesanan, dan Menyimpan pesanan yang diambil ke dalam muatan Driver. Hasil aktual dari pengujian fitur ini sesuai dengan ekspektasi hasil, yaitu tidak ditemukan adanya kesalahan.

Pada Fitur F07-Drop Pesanan, data yang dimasukkan adalah Data Pesanan dan ID Pos. Ekspektasi hasil dari fitur ini adalah barang dalam muatan berubah status menjadi "Menunggu Verifikasi Pos". Hasil aktual dari pengujian fitur ini sesuai dengan ekspektasi hasil, yaitu tidak ditemukan adanya kesalahan.

Pada Fitur F08-Lihat Muatan, data yang dibutuhkan adalah Data pesanan. Ekspektasi hasil dari fitur ini adalah sistem menampilkan daftar pesanan yang sedang dimuat di dalam angkot. Hasil aktual dari pengujian fitur ini sesuai dengan ekspektasi hasil, yaitu tidak ditemukan adanya kesalahan.

Dari kedelapan fungsional tersebut, terdapat tujuh fungsional yang berjalan dengan baik dan sesuai dengan ekspektasi. Namun terdapat satu fungsional yang kurang sesuai dengan ekspektasi, yaitu fitur F01Menampilkan rute pengiriman. Pada beberapa kasus, kode trayek untuk rute pengiriman tersebut tidak muncul.

Selanjutnya, dilakukan pengujian rekomendasi. Pengujian rekomendasi ini menguji ketepatan rekomendasi hasil luaran dari model rule-based system yang telah dibangun. Subjek yang akan digunakan dalam pengujian model ini adalah Driver angkutan kota. Pembuatan skenario pengujian didasarkan pada kombinasi antar variabel yang mempengaruhi model serta pesanan yang masuk. Dengan menggunakan variasi dari keempat variabel, sehingga tercipta 4 skenario yang akan digunakan untuk pengujian model. Tabel 1 merupakan rincian dari masing - masing skenario.

Tabel 1. Skenario pengujian rekomendasi

\begin{tabular}{clc}
\hline No & \multicolumn{1}{c}{ Skenario } & $\begin{array}{c}\text { Jumlah } \\
\text { Test Case }\end{array}$ \\
\hline 1 & $\begin{array}{l}\text { Menggunakan variasi kombinasi antara } \\
\text { kode trayek, jarak, arah, dan kapasitas } \\
\text { dari sebuah angkutan kota dalam }\end{array}$ & 2 \\
mengambil satu buah pesanan. & $\begin{array}{l}\text { Dengan menggunakan variasi kombinasi } \\
\text { antara kode trayek, arah jarak, dan } \\
\text { kapasitas, namun akan ada minimal dua } \\
\text { angkutan kota dalam satu area dengan } \\
\text { sebuah pesanan. }\end{array}$ & 2 \\
3 & $\begin{array}{l}\text { Terdapat tiga pesanan akan diambil oleh } \\
\text { subjek dengan variasi jarak dan arah } \\
\text { Terdapat lima pesanan yang akan } \\
\text { diambil sebagian demi oleh subjek sesuai } \\
\text { urutan jarak }\end{array}$ & 2 \\
\hline
\end{tabular}

Hasil pengujian rekomendasi untuk setiap test case akan di jelaskan berdasarkan subjek yang telah ditentukan pada penelitian ini. Berikut ini merupakan hasil dari tiap test case yang dilakukan :

\section{Test Case 1}

Pada Test Case 1 dilakukan pengujian menggunakan skenario 1 untuk subjek dengan ID Driver 1. Muatan ID Driver belum penuh. Kemudian pada pengujian ini, terdapat 1 pesanan yang terletak pada suatu titik di mana Driver 1 masih berada cukup jauh (>500 meter) dari titik asal pesanan seperti pada Gambar 5. Ekspektasi rekomendasi dari skenario tersebut adalah Tidak ada pesanan yang dapat diambil. Hasil aktual yang didapatkan dari aplikasi sesuai dengan hasil ekspektasi.

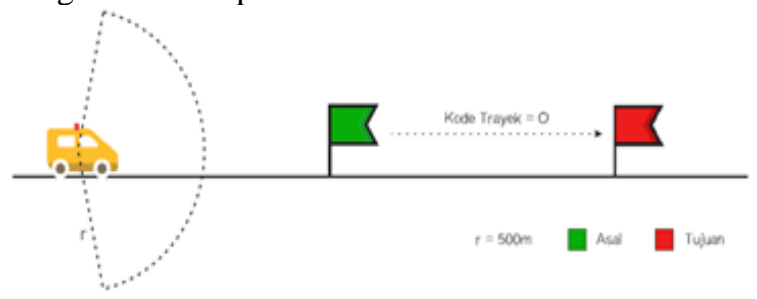

Gambar 5. Ilustrasi Test Case 1

\section{Test Case 2}

Pada Test Case 2 dilakukan pengujian menggunakan skenario 1 untuk subjek dengan ID Driver 2. Pada pengujian ini terdapat 1 pesanan yang terletak pada suatu titik dimana angkot 1 berada cukup dekat ( $<500$ meter ) dari titik asal pesanan. Namun muatan ID Driver 2 sudah penuh. Sehingga ekspektasi rekomendasi dari pengujian ini adalah Tidak ada pesanan yang dapat diambil. Ekspektasi rekomendasi 
ini sesuai dengan hasil aktual dari pengujian test case 2.

\section{Test Case 3}

Pada Test Case 3 dilakukan pengujian menggunakan skenario 2 dengan dua subjek, yaitu ID Driver 1 dan ID Driver 2. Pada pengujian ini terdapat 1 pesanan yang terletak pada suatu titik dimana angkot 1 dan angkot 2 berada pada jarak yang cukup dekat ( $<500$ meter ) dari titik asal pesanan seperti digambarkan pada Gambar 6. Muatan kedua angkot tersebut belum penuh, sehingga ekspektasi rekomendasi dari pengujian ini adalah pada aplikasi kedua Driver angkot tersebut muncul pesanan yang dapat diambil. Hasil aktual dari pengujian ini sesuai dengan ekspektasi rekomendasi.

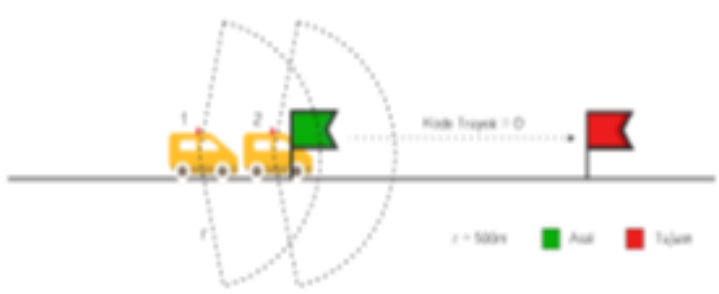

Gambar 6. Ilustrasi Test Case 3

\section{Test Case 4}

Pada Test Case 4 dilakukan pengujian menggunakan skenario 2 dengan dua subjek, yaitu ID Driver 1 dan ID Driver 2. Pada pengujian ini terdapat 1 pesanan yang terletak pada suatu titik dimana angkot 1 dan angkot 2 berada pada jarak yang cukup dekat ( $<500$ meter ) dari titik asal pesanan. Namun muatan keadaan angkot 2 pada saat itu sedang penuh, sehingga ekspektasi rekomendasinya adalah muncul pesanan pada aplikasi Driver angkot 1. Hasil aktual dari pengujian ini sesuai dengan ekspektasi rekomendasi, yaitu pesanan hanya muncul pada aplikasi Driver angkot 1 .

\section{Test Case 5}

Pada Test Case 5 dilakukan pengujian menggunakan skenario 3 untuk subjek dengan ID Driver 1. Pada pengujian ini terdapat dua pesanan dengan titik asal yang sama namun memiliki kode trayek pengiriman yang berbeda. Jarak kedua pesanan dengan angkot cukup dekat $(<500 \mathrm{~m})$. Muatan angkot 1 belum penuh, namun kode trayek pesanan 2 tidak sesuai dengan kode trayek angkot 1. Sehingga ekspektasi rekomendasi dari pengujian ini adalah Hanya pesanan 1 yang muncul pada aplikasi Driver angkot. Hasil aktual dari pengujian ini sesuai dengan ekspektasi rekomendasi.

\section{Test Case 6}

Pada Test Case 6 dilakukan pengujian menggunakan skenario 4 untuk subjek dengan ID Driver 1 . Pada pengujian ini terdapat 5 pesanan yang terletak pada satu titik dimana angkot 1 datang lebih dahulu ke titik asal pesanan. Namun angkot tersebut hanya dapat membawa 3 pesanan untuk dikirimkan ke titik tujuan. Kedatangan angkot 1 ini disusul dua angkot dibelakangnya seperti diilustrasikan pada gambar 7. Sehingga ekspektasi rekomendasi untuk angkot 1 adalah terdapat lima pesanan yang muncul. Kemudian angkot 1 dapat mengambil 3 pesanan untuk diantarkan. Hasil aktual pengujian ini sesuai dengan ekspektasi rekomendasi.

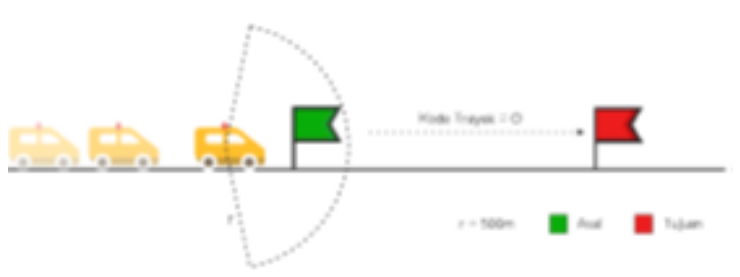

Gambar 7. Ilustrasi Test Case 6

\section{Test Case 7}

Test Case 7 merupakan sekuens dari Test Case 6. Pada Test Case 7 dilakukan pengujian menggunakan skenario 4 untuk subjek dengan ID Driver 2. Pada pengujian ini terdapat 5 pesanan yang terletak pada satu titik dimana angkot 1 datang lebih dahulu ke titik asal dan mengambil 3 pesanan untuk dikirimkan ke titik tujuan. Tidak lama kemudian angkot 2 datang untuk mengambil 2 pesanan yang tersisa seperti diilustrasikan pada Gambar 8. Sehingga rekomendasi pada saat angkot 2 berada dekat dengan pesanan, terdapat dua pesanan yang muncul. Kemudian angkot 2 dapat mengambil 2 pesanan tersisa untuk diantarkan. Hasil aktual pengujian sesuai dengan ekspektasi rekomendasi, yaitu terdapat dua pesanan yang muncul.

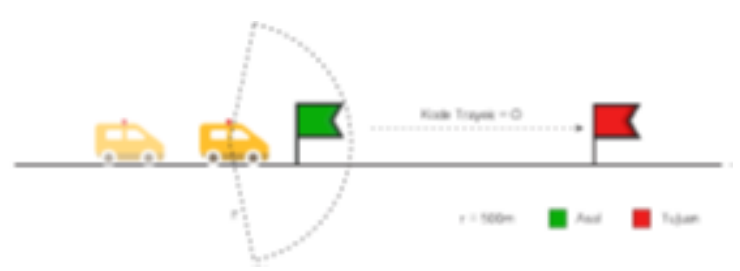

Gambar 8. Ilustrasi Test Case 7

Berdasarkan hasil pengujian dari delapan fitur utama yang terkait dengan penelitian ini, dihasilkan bahwa tujuh fitur yang terdapat pada aplikasi Angkotin dapat berjalan dengan baik tanpa adanya kesalahan atau kendala yang ditemukan. Hasil pengujian juga menyisakan satu fitur untuk menampilkan rute perjalanan yang sebenarnya telah berjalan dengan baik, namun pada beberapa kasus fitur tersebut tidak dapat menampilkan kode trayek untuk pengiriman barang. Hal tersebut menjadi catatan bagi penulis untuk mengembangkan fitur pencarian rute pada API Google Maps.

Hasil dari pengujian model yang telah dilakukan menunjukkan kinerja yang baik dilihat dari ketepatan luaran terhadap hasil yang diharapkan. Dari 7 test case yang dijalankan, semua kasus menghasilkan luaran 
yang sesuai dengan yang diharapkan. Hal ini menunjukkan bahwa metode Rule Based yang digunakan dapat berjalan dengan baik dan dapat digunakan dalam pengaplikasian terhadap kasus pengambilan dan penerimaan pesanan pada angkutan kota.

\section{Kesimpulan}

Pembuatan sistem pendukung keputusan dengan metode rule-based system mampu diimplementasikan untuk menentukan prioritas pengambilan pesanan dalam bentuk aplikasi Angkotin. Aplikasi Angkotin melibatkan tiga jenis pengguna, yaitu pelanggan, pos dan driver angkutan kota. Adapun proses perhitungan model rule-based terletak pada sisi client dari aplikasi driver. Hal tersebut bertujuan untuk memudahkan driver dalam memilih dan mengambil sebuah pesanan. Terdapat empat variabel yang digunakan untuk menentukan prioritas pengambilan pesanan oleh angkutan kota, yaitu jarak, arah perjalanan, status kapasitas dan kode trayek.

Hasil pengujian dari aplikasi Angkotin menunjukkan kinerja yang sangat baik dari sisi fungsional maupun hasil rekomendasi dari model. Pada pengujian fungsional, dari delapan fitur yang diuji terdapat tujuh fitur yang berjalan baik tanpa adanya permasalahan atau kendala. Keberhasilan dalam proses pengujian aplikasi menunjukkan bahwa model yang dibuat menggunakan metode rule-based system telah memenuhi hipotesis untuk dapat digunakan dalam penentuan prioritas pengambilan pesanan oleh angkutan kota.

Penelitian ke depannya yang dapat dilakukan adalah pengembangan fitur pencarian rute pada API Google Maps. Pengembangan fitur tersebut guna untuk memperbaiki fungsional yang kurang sesuai ekspektasi. Selain itu, diharapkan penelitian selanjutnya memiliki prosedur untuk pengiriman barang yang harus melalui dua atau lebih trayek perjalanan.

\section{Daftar Pustaka}

Abraham, A., 2005. Rule-based Expert Systems. Handb. Meas. Syst. Des. 1(g), 909-919.

Asadi, R., Ghatee, M., 2015. A Rule-based decision support system in intelligent hazmat transportation system. IEEE Trans. Intell. Transp. Syst 16 (5), 2756-2764.

Hariyono, D.W., 2015. Penyelenggaraan Angkutan Orang dengan Kendaraan Umum di Surabaya Implementation of Passenger Transport with Public Transport in Surabaya 2 (22), 177-190.

Joewono, T.B., Tarigan, A.K.M., and Susilo, Y.O., 2016. Road-based public transportation in urban areas of Indonesia: What policies do users expect to improve the service quality?. Transp. Policy 49, 114-124.

Mansyur, R., Rahmat, R. A.O.K., Ismail, A., 2013. A prototype rule-based expert system for travel demand management. UNIMAS E-Journal Civ. Eng 44 (1), 34-39.

Panjaitan, J. E., Yuliati, A.L. 2016. Pengaruh kualitas pelayanan terhadap kepuasan pelanggan pada JNE cabang Bandung. DeReMa (Development Research of Manage-ment): Jurnal Manajemen, 11(2), 265-289.

Prasetya, H. D., Legowo, M., 2016. Rasionalitas Ojek Konvensional dalam Mempertahankan Eksistensi di Tengah Adanya Gojek di Kota Surabaya, 7.

Soehodho. S., 2017. Public transportation development and traffic accident prevention in Indonesia. IATSS Res 40 (2), 76-80.

Sudjatmiko, W. D., 2013. Sistem Pendukung Keputusan Pemberian Kredit Pada Koperasi Mitra Mandiri Sejahtera Kota Semarang, pp.1-7.

Tahir, A., 2005. Angkutan massal sebagai alternatif mengatasi persoalan kemacetan lalu lintas kota Surabaya. J. SMARTek 3, 169-182.

Turban, E., Aronson, J.E., Liang, T.P., 2011. Decision Support Systems and Intelligent Systems (7th Edition). Prentice-Hall, Inc., Upper Saddle River, NJ, USA.

Wheatley, M. D., 1984. Expert Systems in TransportPart 1: An Introduction to Expert Systems. 